\title{
Effect of High Density Planting System (HDPS) and Genotypes on Growth Parameters and Yield Contributing Traits in Upland Cotton
}

\author{
Leena B. Parihar ${ }^{1 *}$, T.H. Rathod ${ }^{2}$, A.N. Paslawar ${ }^{3}$ and N.S. Kahate ${ }^{1}$ \\ ${ }^{1}$ Department of Agricultural Botany PGI, ${ }^{2}$ Cotton Research Unit, ${ }^{3}$ Department of Agronomy, \\ Dr. PDKV, Akola \\ *Corresponding author
}

\begin{abstract}
A B S T R A C T
Keywords

High density, Growth parameters, Yield, Upland cotton

Article Info

Accepted:

17 November 2018

Available Online:

10 December 2018

A field experiment was conducted during Kharif season of 2014-15 to evaluate the Effect of High Density Planting System (HDPS) and Genotypes on growth parameters and Yield contributing traits in upland cotton at Cotton Research Unit, Dr. P.D.K.V., Akola. The experiment was laid out in FRBD design consisting of four factors of plant densities viz., $45 \times 10,60 \times 10,75 \times 10$ and $60 \times 15 \mathrm{~cm}^{2}$ in main plots and three factors of cotton varieties i.e., AKH-081, NH-615 and Suraj in sub plots with replicated thrice. The taller plant height, maximum leaf area index and crop growth rate was found with higher plant densities. Whereas more leaf area and total dry matter production were increased with decreased plant densities. Similar trend was obtained with seed cotton yield (g)/plant and single boll weight. The highest seed cotton yield $\left(2428.89 \mathrm{~kg} \mathrm{ha}^{-1}\right)$ was recorded with high density, during both seasons.
\end{abstract}

\section{Introduction}

Cotton (Gossypium hirsutum L.), is one of the most ancient and important commercial crop next to food grains. Due to its importance in agriculture as well as in industrial economy, it is also known as "white gold". In India cotton is grown over an area 105 lakh hectares with production 351 lakh bales and productivity $568 \mathrm{~kg}$ lint ha-1 (Anonymous, 2017). In India, the seed cotton yield per unit area is still far below than many other cotton growing countries in the world. Among the various factors responsible for low yield of cotton crop in the country, low plant population and use of low potential varieties are of primary importance. Various techniques like maintaining suitable plant density, use of optimum dose of fertilizers, growth regulators etc., are being used to overcome these constraints in cotton production. The optimum level of cotton would however depend on the plant type. The present day cotton genotypes have a long duration of 180-200 days; they are late maturing, tall growing and spreading types leading to bushy appearance. They also require the wide spacing resulting in the production of netted canopy there by posing problems in taking up plant protection measures, machine picking, inefficient in 
trapping of solar energy, physiological efficiency and harvest index. Because of longer duration, these varieties require more number of pickings, as a result leading to manifold increase in cost of cotton cultivation especially manual picking and the margin of profit is low and fluctuating in an erratic manner. Moreover, the availability of labour for clean picking is also a serious constraint. At present, in India, entire cotton is picked manually which is labour intensive and is becoming expensive day by day. On the contrary, about 30 per cent of world cotton production in Australia, Israel and USA is machine picked.

In view of the above, present research work carried out with the objective to find out the Effect of High Density Planting System (HDPS) and Genotypes on growth parameters, Yield and Yield contributing traits in upland Cotton at Cotton Research Unit, Dr. P.D.K.V., Akola (M.S).

\section{Materials and Methods}

The experiment was conducted at experimental field of Cotton Research Unit, Dr. P.D.K.V., Akola, during 2014-15. The topography of experimental field was fairly uniform, levelled and with a good drainage. The experiment was laid out in FRBD design with four factors of plant densities i.e. $45 \times 10$, $60 \times 10,75 \times 10$ and $60 \times 15 \mathrm{~cm}^{2}$ in main plots and three factors of cotton varieties i.e., AKH081, NH-615 and Suraj in sub plots. The recommended package of practices was followed during the course of the investigation. The observation on growth parameters were recorded at various crop growth stages $(30,60,90,120 \mathrm{DAS}$ and at harvest) also yield and yield attributes were recorded. The growth parameters i.e., plant height, leaf area, leaf area index, and dry matter production plant $^{-1}$ and CGR were measured. The seed cotton yield (g)/plant from each net plot was picked and the same weighed separately at each picking. The single boll weight was also recorded. The total seed cotton yield $\left(\mathrm{kg} \mathrm{ha}{ }^{-1}\right)$ worked out by summation of a quantity of seed cotton picked in all pickings. The collected data was statistically analysed by Gomez and Gomez (1984) method.

\section{Results and Discussion}

\section{Effect on growth parameters}

Plant height is an important morphological character in cotton, which provides seat for nodes and internodes from where monopodial and sympodial branches emerge (Eaton, 1955) and it play important role in determining morphological framework relating to productivity. The plant height significantly influenced by plant geometry and genotypes throughout its growth stage (Table 1). At 60 DAS, maximum plant height $(43.77 \mathrm{~cm})$ was recorded at $45 \times 10 \mathrm{~cm}$ spacing and it successively increases with increase in crop growth stage. At 90, 120 DAS and at harvest similar spacing recorded maximum plant height i.e. $61.88,74.44$ and $77.28 \mathrm{~cm}$, respectively. Next to that $60 \times 10 \mathrm{~cm}$ plant geometry recorded maximum plant height at all growth stage of plant. Among the genotypes, Suraj noted maximum plant height i.e. $44.20,60.62,75.31$ and $76.23 \mathrm{~cm}$. at 60 , 90, 120 DAS and at harvest, respectively. Next to that, NH615 recorded maximum plant height at all growth stage of plant. Similar result reported by Helemani and Hellikeri (2002) and Srinivasulu et al., (2006).

Data in respect of leaf area per plant as influenced periodically by different treatments (Table 1). The leaf area expanded progressively at $90 \mathrm{DAS}$. Thereafter, there was a decline in leaf area towards harvest stage due to leaf senescence. At 90 DAS, maximum leaf area per plant $(43.77 \mathrm{~cm})$ was 
recorded at $60 \times 15 \mathrm{~cm}$ spacing and it successively decreases with increase in crop growth stage. At 120 DAS and at harvest similar spacing recorded maximum leaf area per plant i.e. 2299.06 and $2155.055 \mathrm{~cm}$, respectively. Next to that $75 \times 10 \mathrm{~cm}$ plant geometry recorded maximum leaf area per plant at all growth stage of plant. Leaf area per plant was higher in wider spacing of $60 \times 15$ $\mathrm{cm}$ with adequate space, light, moisture and nutrient availability, solar radiation penetration and utilization of nutrients in better way to produce higher effective leaf area per plant as compared to closer spacing of $45 \times 10 \mathrm{~cm}$ with higher plant density per unit area which produced higher degree of competition for natural resources and caused reduction in leaf area. Among the genotypes, Suraj recorded significantly maximum leaf area per plant i.e. $1608.21 \mathrm{~cm}$ at 60 DAS.

The leaf area index of various treatments was recorded at various growth stages. The leaf area index expanded progressively and reached to a maximum of $5.17 \mathrm{~g} / \mathrm{cm}^{2}$ during 90 DAS at $45 \times 10 \mathrm{~cm}$ spacing. Thereafter, there was a decline in leaf area index towards harvest stage due to leaf senescence. At 120 DAS and at harvest similar spacing recorded significantly more leaf area index i.e. 4.87 and $4.55 \mathrm{~g} / \mathrm{cm}^{2}$, respectively. Differences among hirsutum genotypes in respect of leaf area index per plant were observed non significant at all stages of crop growth except at 90 and 120 DAS. At 90 DAS and at harvest similar genotype showed significantly maximum leaf area index i.e. 3.77 and $3.55 \mathrm{~g} / \mathrm{cm}^{2}$, respectively. Next to that, AKH081 recorded maximum leaf area index at all growth stage of plant. Leaf area index increases with increasing rate of photosynthates of different hirsutum hybrids due to varietal difference. These results were similar to earlier findings Joshi et al., (2011) and Shukla et al., (2013). Data in respect crop growth rate was recorded at various growth stages. Biomass formed per unit area of land is then of more practical relevance than productivity per plant. At 6090 maximum crop growth rate was recorded in $45 \times 10 \mathrm{~cm}$ i.e., 0.152 . At $90-120$ DAS and 120 DAS - at harvest spacing recorded significantly more crop growth rate i.e. 0.252 and $-0.023 \mathrm{~g} \mathrm{dm}{ }^{-2}$ day- $^{1}$, respectively. Differences among hirsutum genotypes in respect of crop growth rate were observed significant at all stages of crop growth except 60-90 DAS. At 90-120 DAS maximum crop growth rate was recorded in AKH081 i.e. 0.233 .and 120DAS-at harvest the genotype Suraj (-0.026) recorded significantly higher crop growth rate.

\section{Effect on yield parameters:}

\section{Seed cotton yield plant ${ }^{-1}$ (g)}

Data regarding weight of seed cotton plant ${ }^{-1}$ (g) as influenced by different treatments are presented in Table 2. On an average of 15.23 (g) seed cotton yield plant ${ }^{-1}$ was collect in three picking. Treatment differences in respect of seed cotton yield plant $^{-1}$ due to different plant geometry were observed to be significant. Wider plant geometry of $60 \times 15$ $\mathrm{cm}$ i.e. $17.36 \mathrm{~g}$ recorded significantly higher weight of seed cotton yield plant $^{-1}$ as compared to the geometry of $45 \times 10 \mathrm{~cm}$ $(13.71 \mathrm{~g})$. Under wider geometry availability of photosynthates to individual plant was more to produce maximum seed cotton yield as compared to closer plant geometry. This might be due to overall improvement in growth attributes and its positive effect on number of bolls plant ${ }^{-1}$ under wider plant geometry. The above result is in conformity with the findings of Solanke et al., (2001), Raut et al., (2005), Giri et al., (2008) and Reddy and Gopinath (2008). Differences in respect of seed cotton yield plant- $^{1}$ were significant among the three hirsutum genotypes. Genotype AKH081 recorded significantly more seed cotton yield (16.52 g). 
Int.J.Curr.Microbiol.App.Sci (2018) 7(12): 2291-2297

Table.1 Influence of plant geometry and genotypes on growth parameters of Hirsutum cotton

\begin{tabular}{|c|c|c|c|c|c|c|c|c|c|c|c|c|c|c|c|c|}
\hline \multirow[t]{2}{*}{ Treatment } & \multicolumn{4}{|c|}{ Plant Height (cm) } & \multicolumn{4}{|c|}{ Leaf area plant ${ }^{-1}(\mathrm{~cm})$} & \multicolumn{4}{|c|}{ Leaf area index $\left(\mathrm{g} / \mathrm{cm}^{2}\right)$} & \multicolumn{4}{|c|}{ Dry matter production plant $^{-1}$} \\
\hline & $\begin{array}{c}\text { 60 } \\
\text { DAS }\end{array}$ & $\begin{array}{c}90 \\
\text { DAS }\end{array}$ & $\begin{array}{l}120 \\
\text { DAS }\end{array}$ & $\begin{array}{c}\text { At } \\
\text { harvest }\end{array}$ & $\begin{array}{c}\text { 60 } \\
\text { DAS }\end{array}$ & $\begin{array}{c}90 \\
\text { DAS }\end{array}$ & $\begin{array}{c}120 \\
\text { DAS }\end{array}$ & $\begin{array}{c}\text { At } \\
\text { harvest }\end{array}$ & $\begin{array}{c}\text { 60 } \\
\text { DAS }\end{array}$ & $\begin{array}{c}90 \\
\text { DAS }\end{array}$ & $\begin{array}{c}120 \\
\text { DAS }\end{array}$ & $\begin{array}{c}\text { At } \\
\text { harvest }\end{array}$ & $\begin{array}{c}\text { 60 } \\
\text { DAS }\end{array}$ & $\begin{array}{c}90 \\
\text { DAS }\end{array}$ & $\begin{array}{c}120 \\
\text { DAS }\end{array}$ & $\begin{array}{c}\text { At } \\
\text { harvest }\end{array}$ \\
\hline \multicolumn{17}{|c|}{ A)Plant geometry (spacing) } \\
\hline $45 \times 10\left(S_{1}\right)$ & 21.98 & 43.77 & 61.88 & 74.44 & 1506.67 & 2325.56 & 2193.06 & 2049.05 & 3.35 & 5.17 & 4.87 & 4.55 & 39.23 & 58.73 & 95.60 & 92.55 \\
\hline $60 \times 10\left(S_{2}\right)$ & 21.83 & 41.41 & 60.63 & 74.26 & 1535.94 & 2308.00 & 2175.50 & 2031.5 & 2.56 & 3.85 & 3.63 & 3.39 & 39.51 & 59.89 & 97.63 & 93.32 \\
\hline $75 \times 10\left(S_{3}\right.$ & 21.45 & 40.83 & 59.67 & 73.31 & 1545.72 & 2427.28 & 2294.78 & 2150.78 & 2.06 & 3.24 & 3.06 & 2.87 & 40.11 & 60.67 & 102.21 & 97.04 \\
\hline $60 \times 15\left(S_{4}\right)$ & 21.11 & 40.23 & 57.07 & 72.05 & 1561.33 & 2431.56 & 2299.06 & 2155.05 & 1.73 & 2.70 & 2.55 & 2.39 & 41.12 & 61.57 & 102.81 & 97.56 \\
\hline $\operatorname{SE}(\mathbf{m}) \pm$ & 0.79 & 0.65 & 0.46 & 0.56 & 31.99 & 29.37 & 30.82 & 4.38 & 0.10 & 0.01 & 0.01 & 0.10 & 0.11 & 0.26 & 0.13 & 0.11 \\
\hline CD at $5 \%$ & NS & 1.90 & 1.36 & 1.63 & NS & 86.13 & 90.40 & 12.84 & 0.30 & 0.02 & 0.02 & 0.28 & 0.33 & 0.76 & 0.40 & 0.33 \\
\hline \multicolumn{17}{|l|}{ B)Genotypes } \\
\hline $\operatorname{AKH081}\left(V_{1}\right)$ & 20.24 & 39.35 & 59.03 & 72.14 & 1511.75 & 2370 & 2237.5 & 2093.5 & 2.38 & 3.74 & 3.54 & 3.31 & 40.16 & 60.72 & 102.09 & 97.61 \\
\hline NH615 $\left(V_{2}\right)$ & 21.79 & 41.14 & 59.79 & 73.10 & 1492.29 & 2355.29 & 2222.79 & 2078.79 & 2.35 & 3.7 & 3.49 & 3.26 & 39.80 & 59.82 & 97.41 & 93.30 \\
\hline Suraj $\left(V_{3}\right)$ & 22.75 & 44.20 & 60.62 & 75.31 & 1608.21 & 2394 & 2261.5 & 2117.5 & 2.55 & 3.77 & 3.55 & 3.33 & 40.02 & 60.11 & 99.19 & 94.44 \\
\hline $\operatorname{SE}(m) \pm$ & 0.69 & 0.56 & 0.40 & 0.48 & 27.71 & 25.43 & 26.69 & 3.79 & 0.09 & 0.01 & 0.01 & 0.08 & 0.10 & 0.22 & 0.12 & 0.10 \\
\hline CD at $5 \%$ & NS & 1.65 & 1.17 & 1.41 & 81.26 & NS & NS & NS & NS & 0.02 & 0.02 & NS & 0.29 & 0.66 & 0.34 & 0.29 \\
\hline \multicolumn{17}{|c|}{ Interaction $\mathbf{S} \times \mathbf{V}$} \\
\hline $\mathbf{S}_{1} \mathbf{V}_{1}$ & 22.60 & 43.48 & 57.35 & 74.00 & 1623.50 & 2376.83 & 2244.33 & 2100.33 & 3.61 & 5.28 & 4.99 & 4.67 & 40.31 & 60.70 & 98.23 & 94.86 \\
\hline $\mathbf{S}_{1} \mathbf{V}_{2}$ & 22.60 & 44.56 & 57.51 & 74.03 & 1618.67 & 2332.33 & 2199.83 & 2055.83 & 2.70 & 3.89 & 3.67 & 3.43 & 43.00 & 64.79 & 100.97 & 96.54 \\
\hline $\mathbf{S}_{1} \mathbf{V}_{3}$ & 23.50 & 47.03 & 63.18 & 73.14 & 1625.50 & 2355.50 & 2223.00 & 2079.00 & 2.17 & 3.14 & 2.96 & 2.77 & 39.54 & 60.21 & 104.01 & 98.96 \\
\hline $\mathbf{S}_{2} \mathbf{V}_{1}$ & 22.32 & 41.71 & 61.11 & 73.12 & 1565.17 & 2409.33 & 2276.83 & 2132.83 & 1.74 & 2.68 & 2.53 & 2.37 & 37.79 & 57.18 & 105.14 & 100.07 \\
\hline $\mathbf{S}_{2} \mathbf{V}_{2}$ & 21.01 & 42.25 & 64.41 & 73.35 & 1444.00 & 2343.83 & 2211.33 & 2067.33 & 3.21 & 5.21 & 4.91 & 4.59 & 41.32 & 61.69 & 94.73 & 91.96 \\
\hline $\mathbf{S}_{2} \mathbf{V}_{\mathbf{3}}$ & 22.03 & 39.51 & 57.33 & 71.26 & 1515.33 & 2275.50 & 2143.00 & 1999.00 & 2.53 & 3.79 & 3.57 & 3.33 & 38.21 & 58.58 & 96.74 & 92.13 \\
\hline $\mathbf{S}_{3} \mathbf{V}_{1}$ & 21.78 & 40.36 & 60.70 & 70.91 & 1520.33 & 2487.33 & 2354.83 & 2210.83 & 2.03 & 3.32 & 3.14 & 2.95 & 41.49 & 62.32 & 102.62 & 96.56 \\
\hline $\mathbf{S}_{3} \mathbf{V}_{2}$ & 22.35 & 42.43 & 60.06 & 73.03 & 1567.33 & 2393.33 & 2260.83 & 2116.83 & 1.74 & 2.66 & 2.51 & 2.35 & 39.04 & 57.86 & 102.69 & 97.08 \\
\hline $\mathbf{S}_{3} \mathbf{V}_{3}$ & 19.71 & 42.03 & 58.06 & 72.66 & 1452.50 & 2256.00 & 2123.50 & 1979.50 & 3.23 & 5.01 & 4.72 & 4.40 & 41.72 & 62.32 & 93.84 & 90.83 \\
\hline$S_{4} V_{1}$ & 19.98 & 36.63 & 56.36 & 70.90 & 1473.83 & 2316.17 & 2183.67 & 2039.67 & 2.46 & 3.86 & 3.64 & 3.40 & 39.12 & 58.65 & 95.18 & 91.28 \\
\hline $\mathbf{S}_{4} \mathbf{V}_{2}$ & 21.56 & 40.38 & 60.96 & 74.89 & 1491.33 & 2439.00 & 2306.50 & 2162.50 & 1.99 & 3.25 & 3.08 & 2.88 & 37.51 & 57.15 & 100.01 & 95.59 \\
\hline $\mathbf{S}_{4} \mathbf{V}_{3}$ & 19.70 & 38.36 & 60.73 & 73.85 & 1551.50 & 2492.00 & 2359.50 & 2215.50 & 1.72 & 2.77 & 2.62 & 2.46 & 40.85 & 61.15 & 100.61 & 95.52 \\
\hline $\mathrm{SE}(\mathrm{m}) \pm$ & 1.37 & 1.12 & 0.80 & 0.96 & 55.41 & 50.87 & 53.39 & 7.58 & 0.18 & 0.01 & 0.01 & 0.17 & 0.19 & 0.45 & 0.23 & 0.20 \\
\hline CD at $5 \%$ & NS & NS & 2.35 & NS & NS & NS & NS & 22.23 & NS & 0.04 & 0.04 & NS & 0.57 & 1.31 & 0.69 & 0.58 \\
\hline
\end{tabular}




\begin{tabular}{|c|c|c|c|c|c|c|}
\hline \multicolumn{7}{|c|}{$\begin{array}{l}\text { Table.2 Influence of plant geometry and genotype on crop growth rate and yield } \\
\text { parameters of Hirsutum Cotton }\end{array}$} \\
\hline \multirow[t]{2}{*}{ Treatment } & \multicolumn{3}{|c|}{ Crop growth rate } & \multirow{2}{*}{$\begin{array}{l}\text { Seed cotton yield } \\
\text { (g)/plant }\end{array}$} & \multirow[t]{2}{*}{ Single boll weight (g) } & \multirow{2}{*}{$\begin{array}{l}\text { Seed cotton yield } \\
(\mathrm{kg}) / \mathrm{ha}\end{array}$} \\
\hline & $\begin{array}{c}90 \\
\text { DAS }\end{array}$ & $\begin{array}{l}120 \\
\text { DAS }\end{array}$ & $\begin{array}{c}\text { At } \\
\text { harvest }\end{array}$ & & & \\
\hline \multicolumn{7}{|c|}{ A)Plant geometry (spacing) } \\
\hline $45 \times 10\left(S_{1}\right)$ & 0.152 & 0.253 & -0.033 & 13.71 & 2.40 & 2428.89 \\
\hline $60 \times 10\left(S_{2}\right)$ & 0.114 & 0.225 & -0.025 & 14.93 & 2.48 & 2261.00 \\
\hline $75 \times 10\left(S_{3}\right.$ & 0.091 & 0.188 & -0.016 & 15.26 & 2.49 & 1818.17 \\
\hline $60 \times 15\left(S_{4}\right)$ & 0.106 & 0.219 & -0.023 & 17.36 & 2.51 & 1901.17 \\
\hline $\mathrm{SE}(\mathrm{m}) \pm$ & 0.002 & 0.002 & 0.001 & 0.38 & 0.01 & 30.71 \\
\hline CD at $5 \%$ & 0.004 & 0.006 & 0.002 & 1.13 & 0.02 & 90.06 \\
\hline \multicolumn{7}{|l|}{ B)Genotypes } \\
\hline $\operatorname{AKH081}\left(V_{1}\right)$ & 39.35 & 59.03 & 72.14 & 16.52 & 2.48 & 2225.00 \\
\hline $\operatorname{NH615}\left(V_{2}\right)$ & 41.14 & 59.79 & 73.10 & 14.27 & 2.43 & 1991.75 \\
\hline Suraj $\left(V_{3}\right)$ & 44.20 & 60.62 & 75.31 & 15.15 & 2.50 & 2090.17 \\
\hline $\mathbf{S E}(\mathbf{m}) \pm$ & 0.56 & 0.40 & 0.48 & 0.33 & 0.00 & 26.59 \\
\hline CD at $5 \%$ & 1.65 & 1.17 & 1.41 & 0.98 & 0.01 & 78.00 \\
\hline \multicolumn{7}{|c|}{ Interaction $\mathbf{S} \times \mathbf{V}$} \\
\hline $\mathbf{S}_{1} \mathbf{V}_{1}$ & 43.48 & 57.35 & 74.00 & 15.01 & 2.40 & 2671.50 \\
\hline $\mathbf{S}_{1} \mathbf{V}_{2}$ & 44.56 & 57.51 & 74.03 & 15.96 & 2.48 & 2280.50 \\
\hline $\mathbf{S}_{1} \mathbf{V}_{3}$ & 47.03 & 63.18 & 73.14 & 16.27 & 2.50 & 2055.50 \\
\hline $\mathbf{S}_{2} \mathbf{V}_{1}$ & 41.71 & 61.11 & 73.12 & 18.85 & 2.53 & 1892.50 \\
\hline $\mathbf{S}_{2} \mathbf{V}_{2}$ & 42.25 & 64.41 & 73.35 & 12.39 & 2.35 & 2216.50 \\
\hline $\mathbf{S}_{2} \mathbf{V}_{3}$ & 39.51 & 57.33 & 71.26 & 14.08 & 2.46 & 2206.00 \\
\hline $\mathbf{S}_{3} \mathbf{V}_{1}$ & 40.36 & 60.70 & 70.91 & 14.09 & 2.46 & 1808.50 \\
\hline $\mathbf{S}_{3} \mathbf{V}_{2}$ & 42.43 & 60.06 & 73.03 & 16.53 & 2.46 & 1736.00 \\
\hline $\mathbf{S}_{3} \mathbf{V}_{\mathbf{3}}$ & 42.03 & 58.06 & 72.66 & 13.73 & 2.45 & 2398.67 \\
\hline $\mathbf{S}_{4} \mathbf{V}_{1}$ & 36.63 & 56.36 & 70.90 & 14.75 & 2.49 & 2296.50 \\
\hline $\mathbf{S}_{4} \mathbf{V}_{2}$ & 40.38 & 60.96 & 74.89 & 15.43 & 2.52 & 1839.50 \\
\hline $\mathbf{S}_{4} \mathbf{V}_{3}$ & 38.36 & 60.73 & 73.85 & 16.70 & 2.55 & 1826.00 \\
\hline $\mathrm{SE}(\mathrm{m}) \pm$ & 1.12 & 0.80 & 0.96 & 0.67 & 0.01 & 53.19 \\
\hline CD at $5 \%$ & NS & 2.35 & NS & NS & 0.03 & 155.99 \\
\hline
\end{tabular}




\section{Seed cotton yield $\left(\mathrm{kg} \mathrm{ha}^{-1}\right)$}

The differences due to plant geometry in seed cotton yield ha ${ }^{-1}$ were significant. Closer plant geometry of $45 \times 10 \mathrm{~cm}$ recorded significantly higher seed cotton yield $\left(2428.89 \mathrm{~kg} \mathrm{ha}^{-1}\right)$.It was observed that numbers of bolls plant ${ }^{-1}$ were highest under the wider geometry but the seed cotton yield was highest in closer geometry due to the higher plant population than the wider geometry. Similar results were also reported by Raut et al., (2005a), Srinivasan (2006), Sisodia and Khamparia (2007), Giri et al., (2008), Reddy and Gopinath (2008), Bhalerao and Gaikwad (2010) and Reddy and Kumar (2010). Pradeep Kumar et al., (2017) recorded that significantly higher seed cotton yield (2063 $\mathrm{kg} / \mathrm{ha}$ ) was recorded at plant spacing of $45 \mathrm{x}$ $15 \mathrm{~cm}^{2}$ as compared to other spacing. Among the different hirsutum genotypes, genotype AKH081 recorded higher seed cotton yield (2225 kg ha-1).

\section{Single boll weight (g)}

The data reported in table 2 indicate that the difference due to various plant geometry in respect of boll weight was significantly influenced. A wider plant geometry of $60 \times 15$ $\mathrm{cm}$ produced more boll weight $(2.51) \mathrm{g}$.The variation in boll weight in plant geometry was due to fact that the better aeration and adequate interception of light and lesser competition of nutrients at wider spacing, which resulted in synthesis of higher photosynthates and thereby helped to produce higher boll weight. Differences in respect of seed cotton yield plant-1 were significant among the three hirsutum genotypes. Genotype AKH081 (V1) recorded significantly more seed cotton yield $(16.52 \mathrm{~g})$. This increase in seed cotton yield might be due to more number of bolls per plant, boll weight per plant as compaired to local check (Nehra et al., 2004). The boll weight is major yield components in G. hirsutum cotton under rainfed condition (Singh et al., 1983).

In conclusion, on the basis of experimental study of cotton (Gossipium hirsutum) genotype AKH081 can be sown at plant spacing of $45 \times 10 \mathrm{~cm}$ for obtaining higher seed cotton yield respectively over the spacing.

\section{References}

Anonymous, 2017. Annual progress report of cotton. www.cab.com

Bhalerao, P.D. and Gaikwad G.S., 2010. Productivity and profitability of $\mathrm{Bt}$ cotton (Gossypium hirsutum) under various land geometry and fertilizer levels. Indian Journal of Agronomy. 55(1): 60-63.

Eaton, F.M. 1955. Physiology of cotton plant. Annual Reviews of Plant Physiology. 6: 299-328.

Giri, A. N., Aundhekar R. L., Kaps P. S. and Suryavanshi S. B., 2008. Response of Bt cotton hybrids to plant densities and fertilizer levels. J. Cotton Res. Dev. 22(1):45-47.

Gomez, K. A. and Gomez A. A., 1984. Statistical procedure for Agricultural Research. An International Rice Research Institute Book. A Willey Inter Science Publication, New York.

Hallemani, H. L. and Hallikeri S. S., 2002. Response of compact and early maturity genotypes to plant population levels under rainfed condition. J. Cotton Res. Dev. 16(2): 143-146.

Joshi, P., Biradar D. P., Patil V. C., Janagagouda B. S., Patil B. R. and Udekeri S. S., 2011. Evaluation of commercially available $\mathrm{Bt}$ cotton genotypes for their Agromic performance and economic returns. Karnataka J. Agric. Sci., 24(3): 277279.

Nehra, P. L., Nehra K. C. and Kumawat P. D., 
$2004^{\mathrm{a}}$. Response of hirsutum cotton to wider row spacing and potassium in north-western plain zone of Rajasthan. J. Cotton Res. Dev. 18(2): 184-186.

Pradeep Kumar., Karle, A.S., Sing D. and Verma, L. 2017. Effect of high density planting system (HDPS) and varieties on yield, economics and quality of desi cotton. Int. J. of Curr. Microbio. and Applied Sci. ISSN: 2319-7706 Volume 6(3): 233-238.

Raut, R. S., Thokale J. G. and Mehetre S. S., $2005^{\mathrm{a}}$. Response of cotton cultivars to varying spacing and fertility levels. $J$. Cotton Res. Dev. 19(2): 191-193.

Raut, R. S., Thokale J. G. and Mehetre S. S., $2005^{\mathrm{b}}$. Effect of fertilizer and spacing on interspecific hybrid Phule-388 under summer irrigated conditions. J. Cotton Res. Dev. 19(2): 200-201.

Reddy, P. R. and Gopinath R. M., 2008. Influence of fertilizers and plant geometry on performance of Bt cotton hybrids. J. Cotton Res. Dev. 22(1): 7880.

Reddy, R.R.P. and Kumar D. B., 2010 Yield and economics of $\mathrm{Bt}$ cotton as influenced spacing and nutritional levels. PKV Res. J. 34(1): 20-22.

Shukla, U.N., Khakare, M.S., Srivastava,
V.K., Kumar, R., Singh, S., Kumar, V and Kumar, K. 2013. Effect of spacings and fertility levels on growth, yield and quality of cotton (Gossypium hirsutum L.) hybrids under rainfed condition. Bioinfolet. 10 (3B): 937- 942.

Singh, V.V., Singh, P and Bhat, M.G. 1983. Study of yield components in rainfed American cotton. ISCI Journal. 1-4.

Sisodia, R.I. and Khamparia S.K., 2007. American cotton varieties as influenced by plant densities and fertility levels under rainfed conditions. J. Cotton Res. Dev. 21(1): 35-40.

Solanke, V. M., Turkhede A.B., Katkar R. N., Wankhade S. T. and Sakhare B. A., 2001. Response of cotton hybrids to various agronomic practices. Crop Res. 21(1): 30-33.

Srinivasan, G. 2006. Agronomic evolution of Bt cotton hybrids in summer irrigated tract of Southern Tamilnadu. J. Cotton Res. Dev. 20(2): 224-225.

Srinivasulu, K., Hema, K., Narayana, E., Prasad, N.V.V.S.D. and Rao, N.H.P. 2007. Agronomic evaluation of $\mathrm{Bt}$. Hybrid (NCS-207 Bt.) in Vertisols of Andhar Pradesh under rainfed conditions. J. Cotton Res. Dev. 21(2): 179-1

\section{How to cite this article:}

Leena B. Parihar, Rathod, T.H., Paslawar, A.N. and Kahate, N.S. 2018. Effect of High Density Planting System (HDPS) and Genotypes on Growth Parameters and Yield Contributing Traits in Upland Cotton. Int.J.Curr.Microbiol.App.Sci. 7(12): 2291-2297. doi: https://doi.org/10.20546/ijcmas.2018.712.260 